\title{
The Reduction in the Swelling Potential of the Foundation Ground of Togblécopé in Togo by the Stabilization with Binders and Sands
}

\author{
Kossi Bolanigni Amey1*, Komi Mawutodzi Sounsah², Komla A. S. Amoussou ${ }^{2}$, Koumah Neglo \\ ${ }^{1}$ Ecole NationaleSupérieure des Ingénieurs(ENSI) de l'Universitéde Lomé (UL), Lomé, Togo \\ ${ }^{2}$ Equipe de Recherche et Devéloppement de FORMATEC, Lomé, Togo \\ Email: formatec03@yahoo.fr, *ameykoss3@yahoo.fr
}

How to cite this paper: Amey, K.B., Sounsah, K.M., Amoussou, K.A.S. and Neglo, K. (2018) The Reduction in the Swelling Potential of the Foundation Ground of Togblécopé in Togo by the Stabilization with Binders and Sands. Open Journal of Civil Engineering, 8, 221-233.

https://doi.org/10.4236/ojce.2018.82017

Received: April 19, 2018

Accepted: June 26, 2018

Published: June 29, 2018

Copyright (ㅇ 2018 by authors and Scientific Research Publishing Inc. This work is licensed under the Creative Commons Attribution International License (CC BY 4.0).

http://creativecommons.org/licenses/by/4.0/

\section{(c) (i) Open Access}

\begin{abstract}
The present study aims at helping to search for preventive solutions to pathologies of constructions in Togblécopé in Togo, by the reduction in the withdrawal and swelling of foundation grounds through their stabilization. Togblécopé's clay taken from $1 \mathrm{~m}, 2 \mathrm{~m}$ and $3 \mathrm{~m}$ deep, and mixed with four binding materials (cement, sea sand, silty sand and lime). Tests of identification and free swelling with odometer are carried out on pure and stabilized materials. What emerges from these tests is that the limits of liquidity and plasticity are rising along with the rate of stabilizers while the index of plasticity is falling. Cement and lime cause a reduction in the index value of plasticity by almost $50 \%$. The more the sand's grain size, the more the reduction in the plasticity index. The swelling potential is reduced by $60 \%$ for cement and lime, $30 \%$ for sea sand and $20 \%$ for silty sand. The present study is a contribution to the reduction in deflations from $20 \%$ to $60 \%$ of some parts of constructions in order to limit cracks.
\end{abstract}

\section{Keywords}

Swelling Ground, Togo, Stabilization, Binder, Sands

\section{Introduction}

Civil engineering works aim at soils called foundation soil that is mostly clayey soils. Some clays present swelling or retracting features. Construction on such a clayey soil requires a thorough campaign of research, identification and characterization of its swelling potential. Swelling soils are very fine soils whose 
components are made up of layers. The swelling feature is a very complex issue, since it is the outcome of several associated phenomena that cannot be separated in terms of experiment for identification of each mechanism effect [1]. In dry season, swelling soils lose their saturation and the quantity of water falls down. They undergo a relatively significant reduction in volume; conversely, when they become hydrated again, the water goes through cracks and tends to capture its initial volume. Such swelling of clays depends on the state of soil capacity and on hydric conditions. The presence of swelling soils poses then a great deal of problems for designers of works [2]. A large number of works, constructed on marneous formations, show very often signs of degradations. These latter, characterized by cracks at the superstructure, are due to the phenomenon of withdrawal which has not been considered during their implementation and which are getting worse in the dry season. Moreover, the resulted deformations are not uniform following all directions because of the anisotropic structure of the material and depend mainly on the state of applied constraint.

Therefore, the treatment of soils is often used to upgrade their resistance in order to reduce or to increase their permeability and also to lower their compressibility [2] [3]. It is also used to reduce the soil sensitiveness to variations of the water content as is the case with expansive soils [4] [5].

In Togo, or more exactly in Togblécopé, living quarters and other constructions go through sweeping degradations (Figure 1). We have been experiencing for many decades an instability characterized by a state of construction with widespread subsidence and cracking in different parts of constructions. The causes of such degradations can be searched in the instability of soil that is swelling and then subject to bad weather. This work aims to help search for preventive solution to deformations of constructions in Togblécopé in Togo through the study of swelling soils in the region. Additional lime, cement, sea sand and silty sand are used to help reduce instability of the soil by reduction in its withdrawal and swelling.

\section{Materials and Methods}

\subsection{Materials}

- The clay samples are taken from Togblécopé, a suburb located in northern area of Lomé, the capital town of Togo, about $20 \mathrm{~km}$ far from the downtown (Figure 2). The Togblécopé's soil is a depression of the Zio River, made up of a metamorphic complex that is rich in basic minerals. This complex contains metamorphic rocks that are rich in amphibole and are derivatives of gneiss.
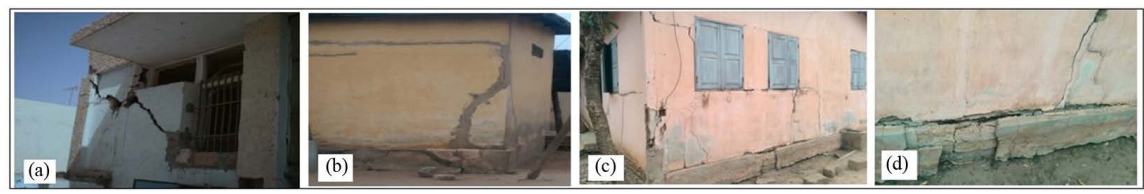

Figure 1. Photograph of partial views of some degraded buildings. 


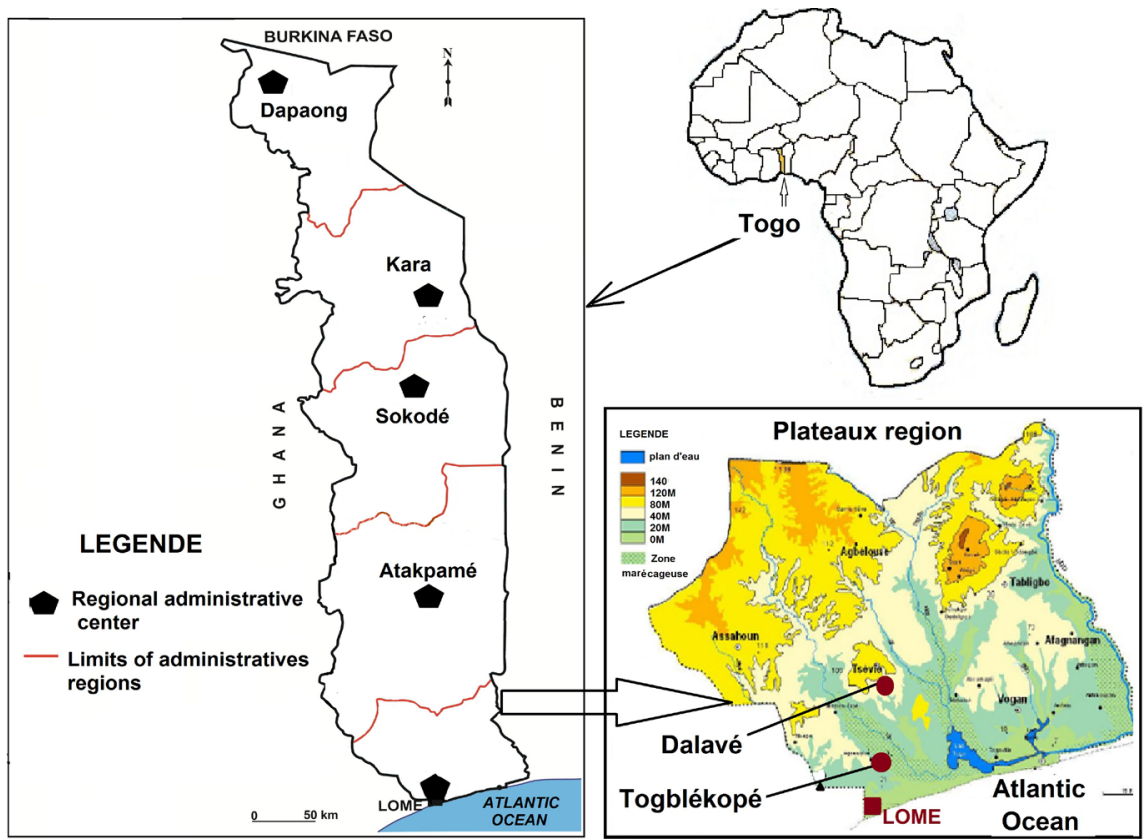

Figure 2. Situation of the area where clay is tested.

The coastal basin (Maastrichtian to Holocene) stretches up to Tsévié and Tabligbo and consequently covers all over this suburb. This basin is composed of sand, clay, limestone and phosphate [6].

- The CPJ 35 cement manufactured by CIMTOGO and delivered in bags of 50 $\mathrm{kg}$ and the lime of the brand CALVIVA, delivered in bags of $25 \mathrm{~kg}$ are taken as samples in a commercial store of Lomé in Togo.

- Silty sand and siliceous sand (sea sand) for stabilization, are taken respectively at Dalavé, $35 \mathrm{~km}$ in northern area of Lomé on Togo's littoral in Lomé (Figure 2)

- For different tests the following material is used: manual shaker; mechanical diving shaker with a speed equal to $10,000 \mathrm{tr} / \mathrm{mn}$ of the brand MATEST with a vessel; torpedo densimeter with range 0.995 to 1.035 ; tubes of brand CHEKAMAT and capacity of $2500 \mathrm{ml}$; consolidation device; oedometric cell of brand S272-01, serial number S272-01/AC/0007; piston of oedometric system; comparator at $1 / 100 \mathrm{~mm}$; Casagrand device with cup of the brand LABOTEST and serial number Z10248; groover; dryer of the brand Air-Expert with maximal temperature $160^{\circ} \mathrm{C}$; a pycnometer of minimal volume of $500 \mathrm{~cm}^{3}$ with roded top; a precision scale of the brand METTLER TOLEDO with a maximal capacity of $5 \mathrm{~g}$ and a precision of $0.1 \mathrm{~g}$; a sieve system AFNOR.

The tests are carried out in the laboratory Lab-TP (Laboratory of Public Works) of Lomé in Togo.

\subsection{Methods}

Samples of reorganized or intact clayed soil are taken from $1 \mathrm{~m}, 2 \mathrm{~m}$, and $3 \mathrm{~m}$ 
deep well on the soil of Togblécopé.

The stabilization of the clay from different depths is performed with cement, lime, sea sand and silty sand by proportions of $0 \%$ to $10 \%$ and at paces of $2 \%$ of the material mass.

Physical tests (density, limits of liquidity WL and plasticity WP, equivalent of sand ES and granulometries by sieving and sedimentation) are then carried out on such different materials as clay, sands and on mixtures according to standards [7] [8] [9].

The free swelling is measured with oedometer on samples subject to the only weight of $1080.22 \mathrm{~g}$ of piston (Figure 3). The preparation procedure of samples is the following (Figure 4) [10]:

- Saturation of porous stones for at least 1 hour in a water pit;

- Laying of a porous stone at the base with filter paper;

- Laying of sample of soil cut up in the ring on the basic porous stone;

- Laying of a filter paper on the surface of the sample;

- Laying of the second porous stone and blocking of the whole;

- Positioning of the cell on its plate;

- Filling of the tank with distilled water for the saturation.

The variation of the height of the sample is measured according to the duration of application of the charge $(12,24,48,60,120,240,480,900,1800,3600$,

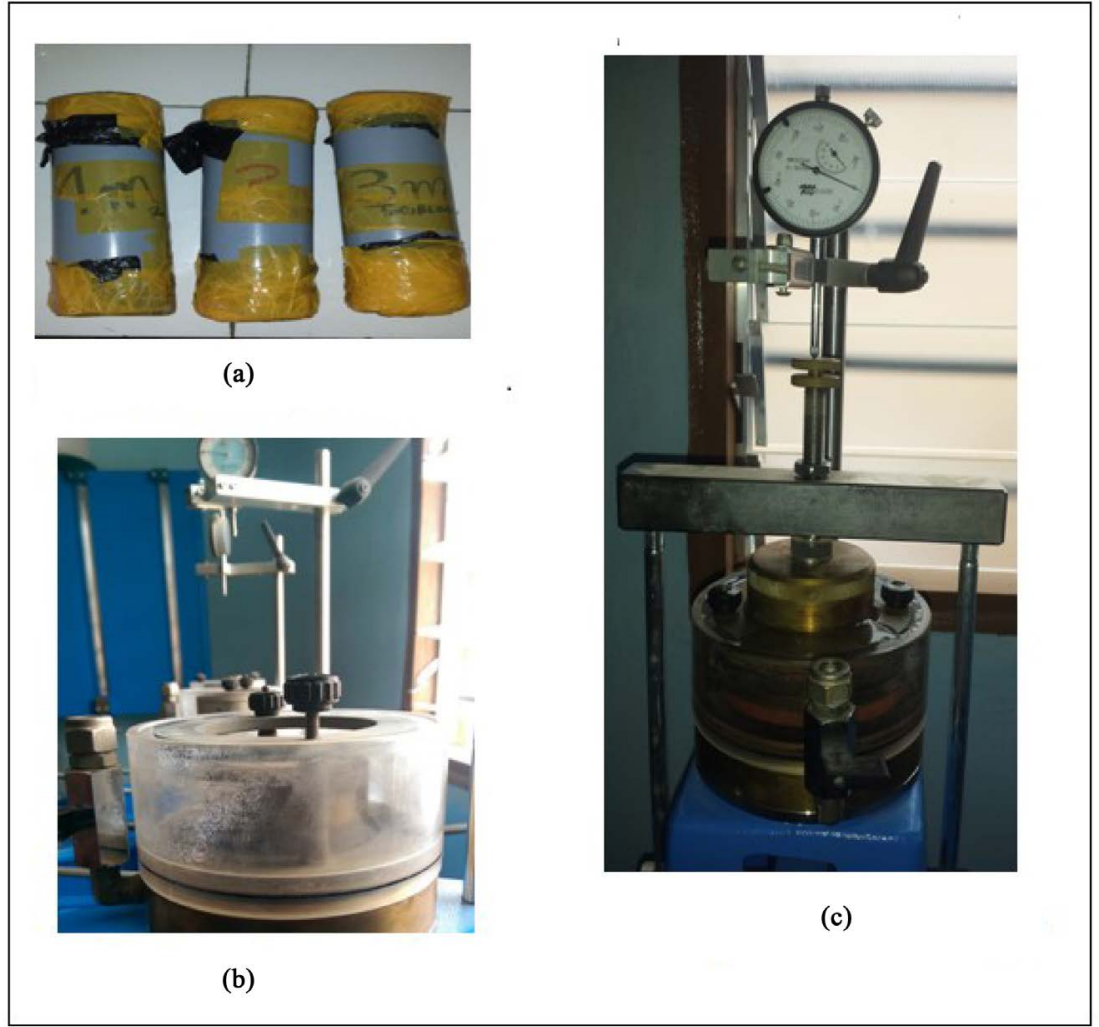

Figure 3. Device of tests of measuring the reduction in swelling. (a) Intact samples; (b) Sample in cell; (c) Sample under charge. 


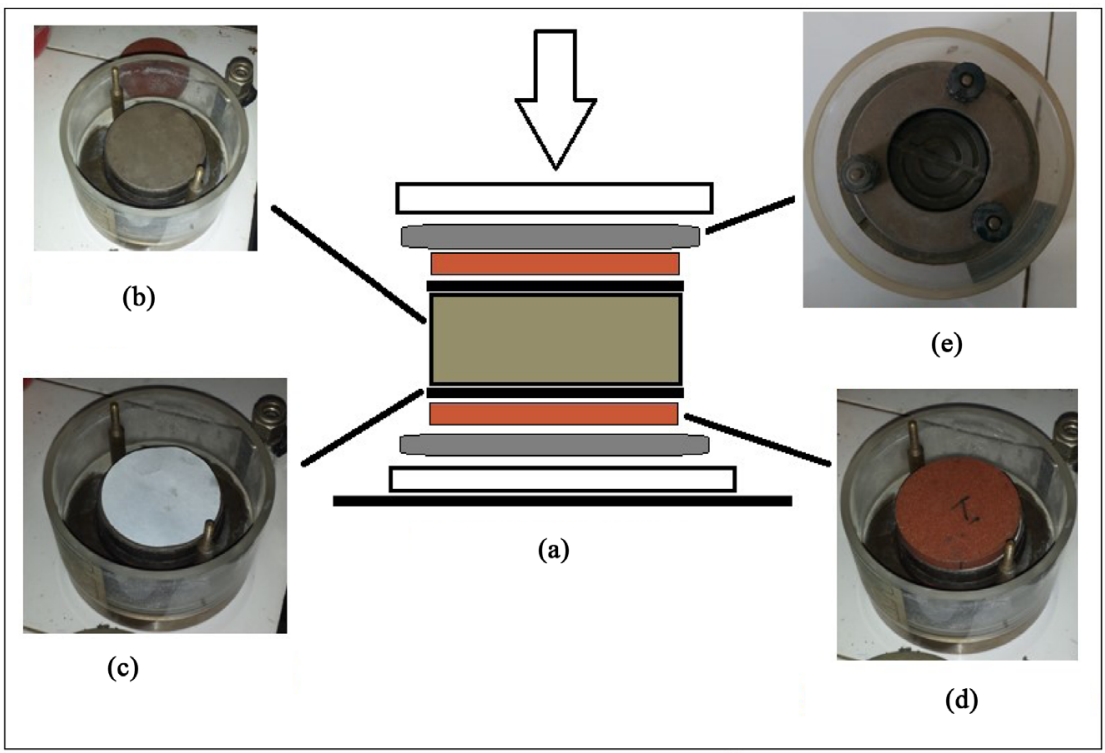

Figure 4. Device of the putting up of the cell. (a) Complete device of the cell; (b) Sample in the cell; (c) Membrane laying; (d) Laying of porous stone; (e) Laying of the cell plate.

$7200,14,400,21,600,28,800$ in s) until it stabilizes. The sample is considered stable when the difference of reading between two successive times does not exceed $0.001 \mathrm{~mm}$.

The reduction in final swelling $R g(\%)$ is given by:

$$
R g=\frac{\Delta G}{G_{0}}=\frac{G_{0}-G_{a}}{G_{0}}
$$

With $R g$ the relative reduction in final swelling; $G_{o}$ the reduction in the swelling of pure clay; $G_{a}$ the reduction in the swelling of stabilized clay.

\section{Results}

\subsection{Results of Characteristics of Clay and Sand Materials}

The results of physical tests on the sand and clay materials are given in Table 1 and Figure 5 and Figure 6.

Table 1 and Figure 5 and Figure 6 show that:

- Dalavé's silty sand has an extended granulometry with a big proportion of sieved sands $0.08 \mathrm{~mm}$ of $20.60 \%$ with a module of fineness of 1.39 and an equivalent sand of 55. It falls then under the category of very fine sands [11];

- the sea sand doesn't contain components that are below $0.160 \mathrm{~mm}$; It has a module of fineness of 2.52 and an equivalent sand of 97.5. This sand is then of medium-sized granulometry [12] [13];

- the sieved sample sands of $0.08 \mathrm{~mm}$ taken at $1 \mathrm{~m}, 2 \mathrm{~m}$, and $3 \mathrm{~m}$, are respectively of $75.53 \%, 82.64 \%$ and $76.71 \%$. These values are much higher than $50 \%$; the clayed materials from Togblécopé contain then a large proportion of fine grains. Besides, absolute densities of $1 \mathrm{~m}, 2 \mathrm{~m}$, and $3 \mathrm{~m}$ deep can be observed with respectively 2.50, 2.53, 2.54 and indexes of plasticity (Ip) of 25.24, 


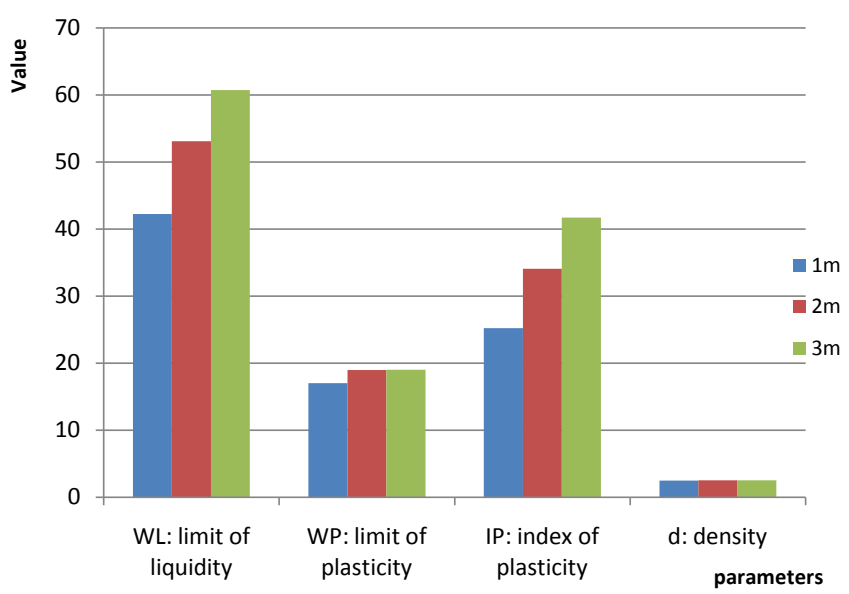

Figure 5. Absolute density and limit of Atterberg of clay.

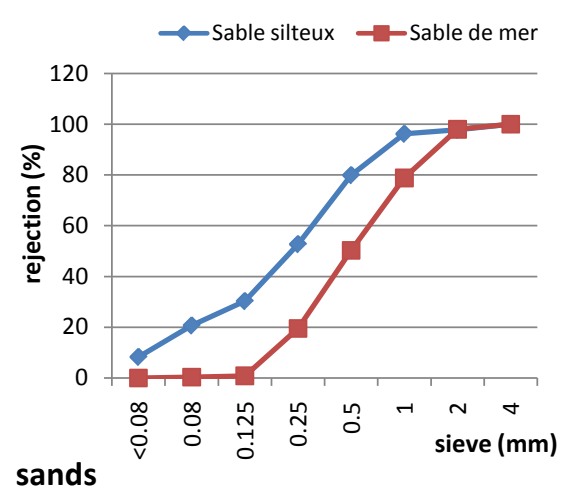

(a)

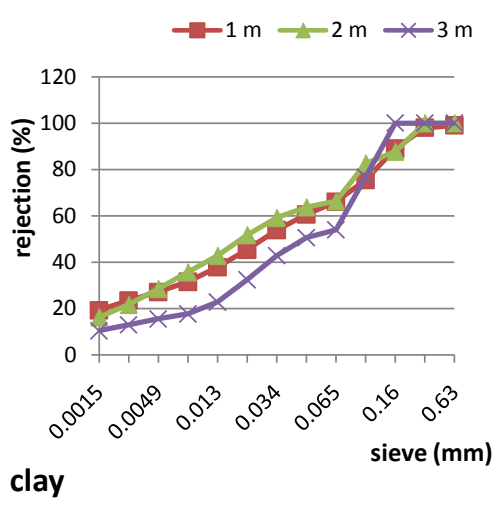

(b)

Figure 6. Results of sieving of materials

Table 1. Results of tests of density, module of fineness and equivalent of sand.

\begin{tabular}{ccccc}
\hline \multirow{2}{*}{ Materials } & \multirow{2}{*}{$\begin{array}{c}\text { Module of } \\
\text { fineness }\end{array}$} & \multicolumn{2}{c}{ Density } & \multirow{2}{*}{$\begin{array}{c}\text { Equivalent de sand } \\
\text { (ES in \%) }\end{array}$} \\
\cline { 3 - 4 } & 1.39 & 1.59 & 2.61 & 55 \\
Silty sand & 2.52 & 1.54 & 2.65 & 95.7 \\
Sea sand & & Apparent & Absolute & \\
\hline
\end{tabular}

34.09 and 41.73. The samples taken at $1 \mathrm{~m}$ and $2 \mathrm{~m}$ deep can then be considered as plastic whereas those taken at $3 \mathrm{~m}$ deep are very plastic. The soils of Togblécopé are therefore more and more plastic and dense in depth than on the surface. This Togblécopés soil is an instable land composed of swelling clay.

\subsection{Results of Characteristics of Composite Materials}

The results of the average of the limit of liquidity and densities of different composite samples (clays, stabilizers) of different depths are shown in Figure 7 and Figure 8. 


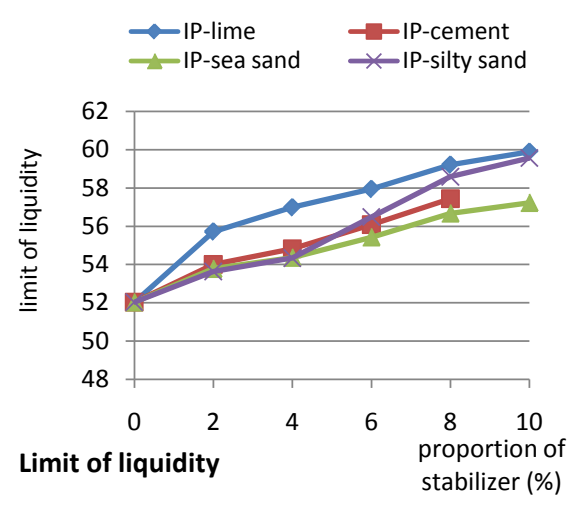

(a)

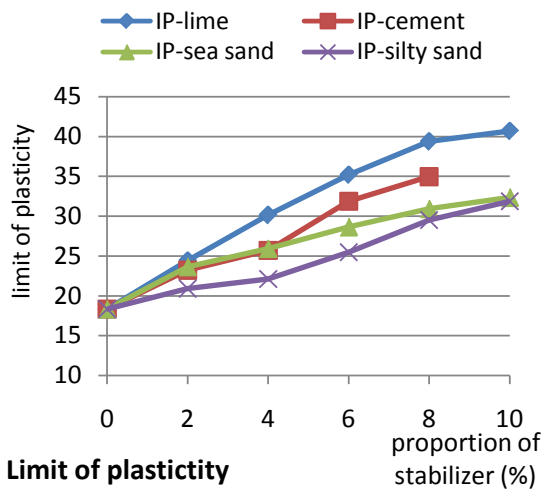

(b)

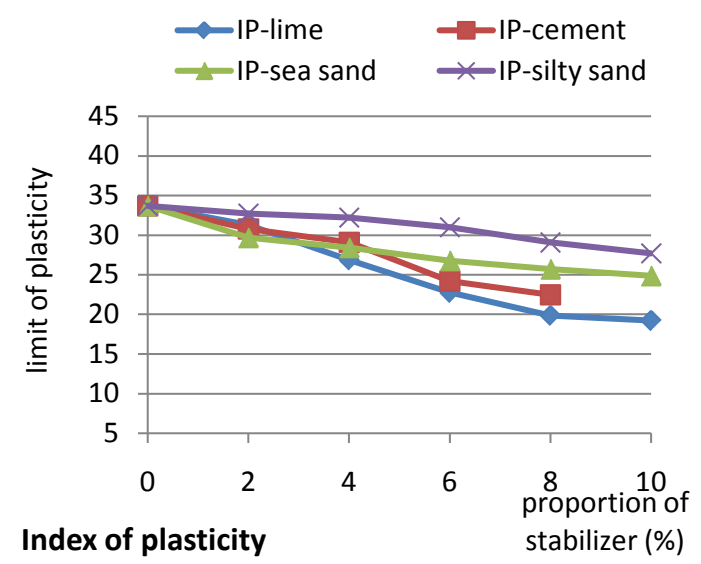

(c)

Figure 7. Variation of limits of Atterberg according to proportions of stabilizers

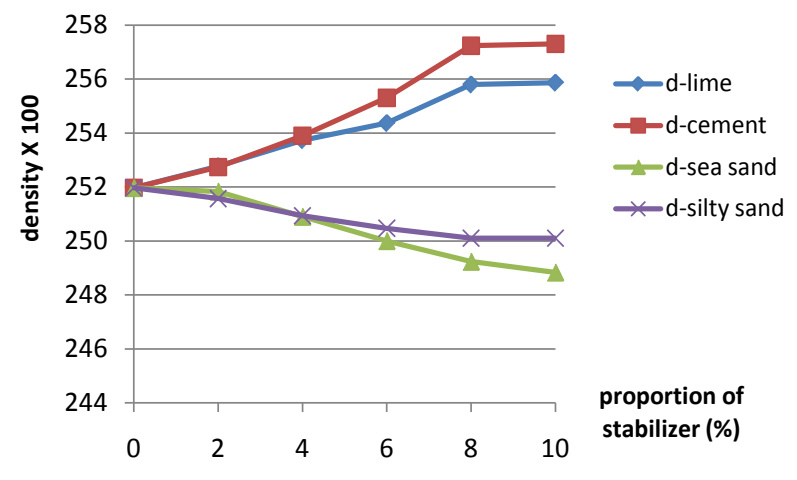

Figure 8. Variation of densities according to proportions of stabilizers.

By examining Figure 7 and Figure 8 the following can be noticed:

- a rise in limits of liquidity and plasticity as the proportion stabilizer increases (Figure 7(a) and Figure 7(b));

- a reduction in the index value of plasticity while the percentage of stabilizer grows (Figure $7(\mathrm{c})$ ); its reduction accelerates depending on whether the sand is thicker (Figure $7(\mathrm{c})$ ); 
- the stabilization with hydraulic binders (lime and cement), presents densities that grow with their dosages; however, densities decrease with the rise in the proportion of sands (Figure 8);

- cement makes clay denser than lime; the density is lower in the case of stabilization with the sea sand than that of silty sand (Figure 8).

\subsection{Results of Mechanical Tests: The Free Swelling}

Figure 9 to Figure 13 show the averages of results of different depths, reductions in swellings of different stabilizers.

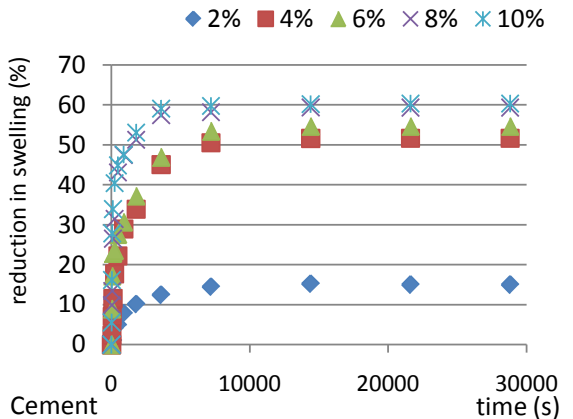

(a)

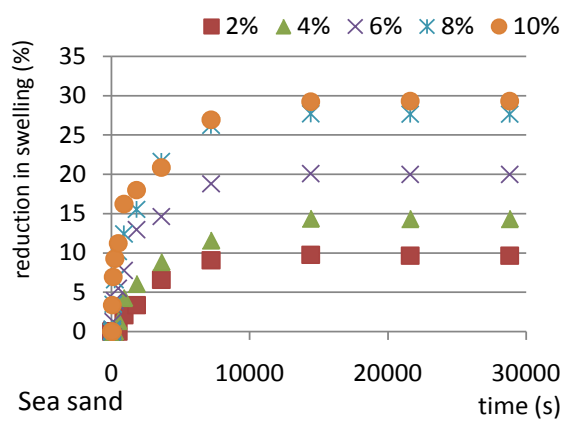

(c)

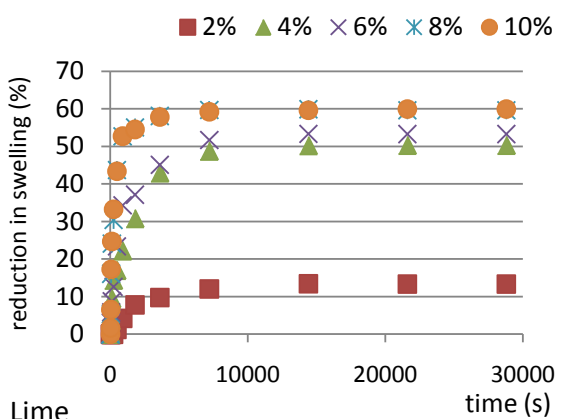

(b)

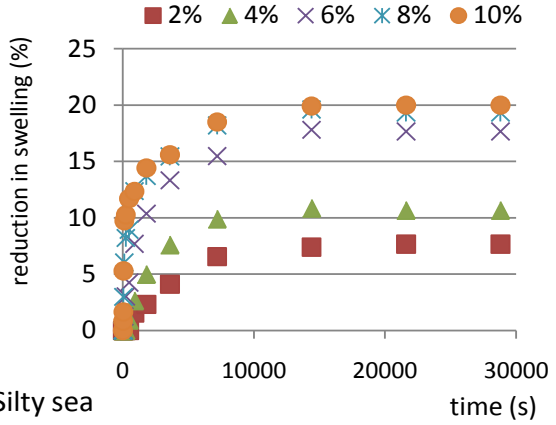

(d)

Figure 9. Variation of the reduction in potential of swelling according to time for the different stabilizers.

Figure 9 to Figure 13 show that:

- in average $62 \%$ of the reduction in the potential of swelling occurs after 30 minutes for the hydraulic binders whereas it is $32 \%$ for sands. After 2 hours, $97 \%$ of the reduction in swelling occurs for the binders and $89 \%$ for the sands. After 8 hours, $100 \%$ of the potential of swelling occurs. The equations of levelling of results of proportion of stabilizer of $10 \%$, providing the highest reduction, are shown in (Figure 11):

$$
\begin{gathered}
R_{\text {gcimt }}=8.717 \ln (t)-14.22 \text { and } R^{2}=0.921 \text { if } t<4986 \\
R_{\text {gcimt }}=60 \text { if } t>4986 \\
R_{\text {gcht }}=9.832 \ln (t)-23.79 \text { and } R^{2}=0.935 \text { if } t<5025
\end{gathered}
$$




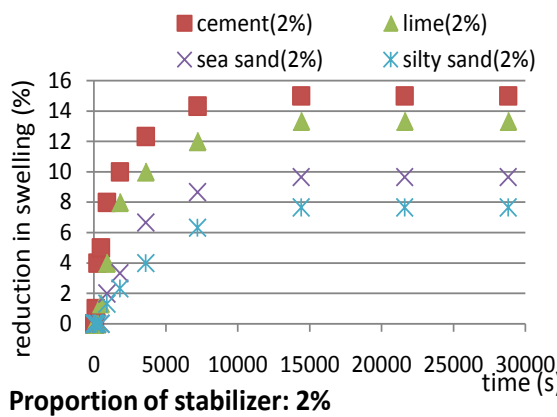

(a)

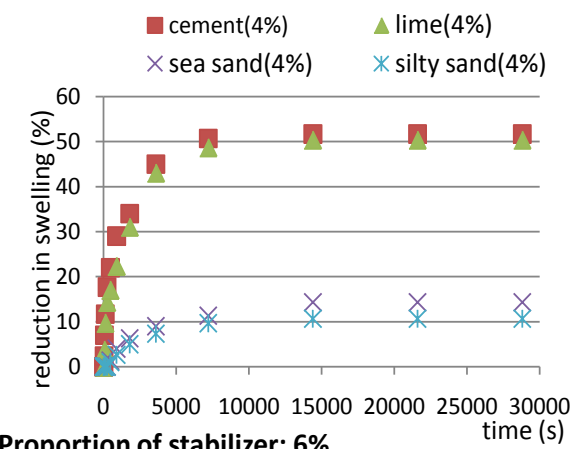

Proportion of stabilizer: $6 \%$

(c)

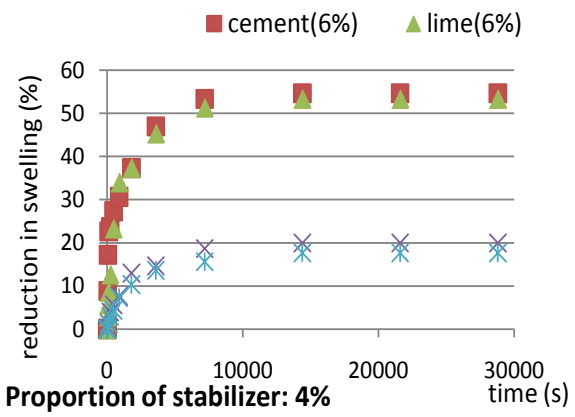

(b)

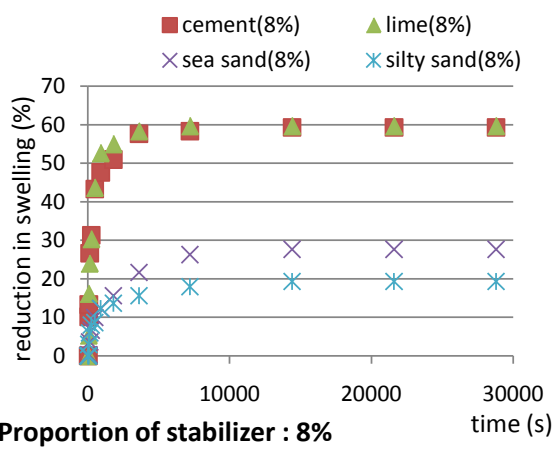

(d)

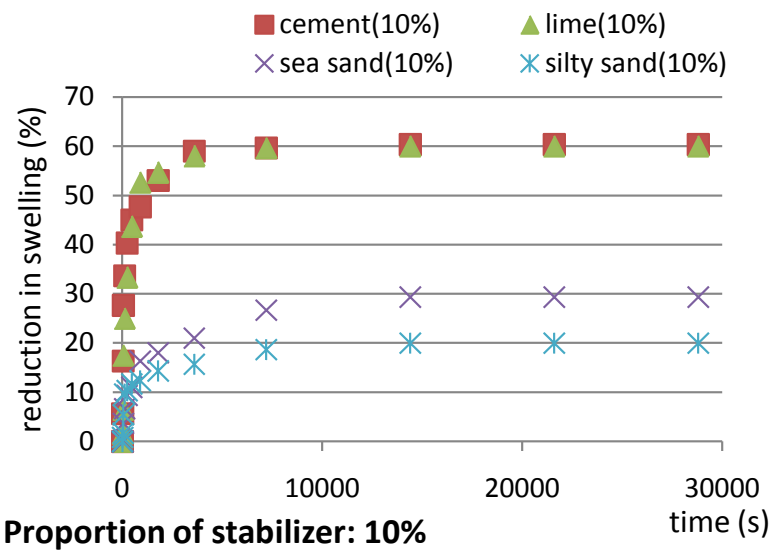

(e)

Figure 10. Variation of the reduction in potential of swelling according to time for the different mixtures in stabilizers.

$$
\begin{gathered}
R_{g c h t}=60 \text { if } t>5025 \\
R_{g s m t}=4.435 \ln (t)-14.41 \text { and } R^{2}=0.975 \text { if } t<19200 \\
R_{g s m t}=29.33 \text { if } t>19200 \\
R_{g s s t}=2.877 \ln (t)-6.977 \text { and } R^{2}=0.958 \text { if } t<11800 \\
R_{g s s t}=20 \text { if } t<11800
\end{gathered}
$$

$R_{\text {gcimt }}, R_{g c h}, R_{g s m t}$ and $R_{g s s t}$ are respectively reduction in swelling for such additional components as cement, lime, sea sand and silty sand with $t$ the time in $s$. 
- for $10 \%$ of stabilizers the four additional components largely reduced the potential of swelling up to $60 \%$ for cement and lime, $30 \%$ for sea sand and $20 \%$ for silty sand (Figure 11);

- The reduction in swelling goes up with the rise in the proportion of stabilizer (Figure 12); the equations of levelling from these results are the following:

$$
\begin{aligned}
& R_{g c i m T}=-0.883 T^{2}+15.09 T-2.881 \text { and } R^{2}=0.952 \\
& R_{g c h T}=-0.837 T^{2}+14.69 T-3.297 \text { and } R^{2}=0.949 \\
& R_{g s m T}=-0.125 T^{2}+4.197 T+0.428 \text { and } R^{2}=0.988 \\
& R_{g s s T}=-0.180 T^{2}+3.829 T+0.011 \text { and } R^{2}=0.983
\end{aligned}
$$

$R_{g c i m T}, R_{g c h T}, R_{g s m T}$ and $R_{g s s T}$ are respectively reduction in swelling for such additional components as cement, lime, sea sand and silty sand with $T$ the proportion of stabilizer in \%.

- for $4 \%$ of the proportion of lime and cement, the reduction in swelling is very pronounced; from $8 \%$ of all the stabilizers, the reduction in the potential of swelling stabilizes (Figure 12);

- the swelling is more reduced with the hydraulic binders than that of sand; it is also more pronounced for the stabilizer sea sand than that of silty sand (Figures 10-12);

- the potential of reduction in swelling increases with the limits of liquidity and plasticity, it also rises with the index of plasticity (Figure 13); thus, the more plastic the material the more the reduction in swelling is reduced.

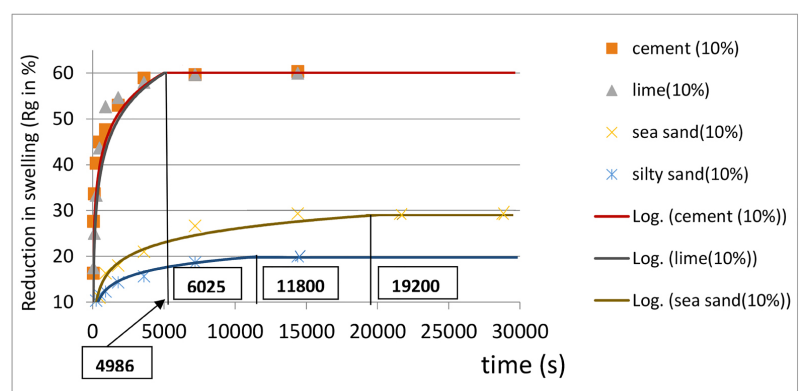

Figure 11. Variation of the reduction in potential of swelling according to time for the different mixtures of $10 \%$ in stabilizer.

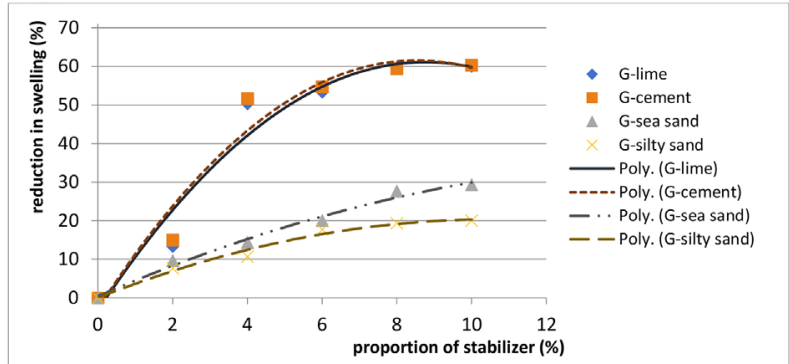

Figure 12. Reduction in potential of swelling according to the proportion of stabilizer. 


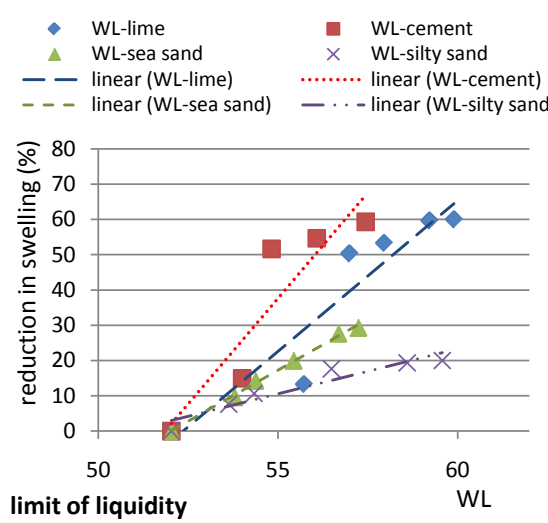

(a)

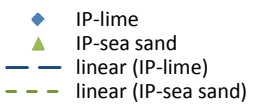

- IP-cement $\times \quad$ IP-silty sand ...... linear (IP-cement) - - - - linear (IP-silty sand)

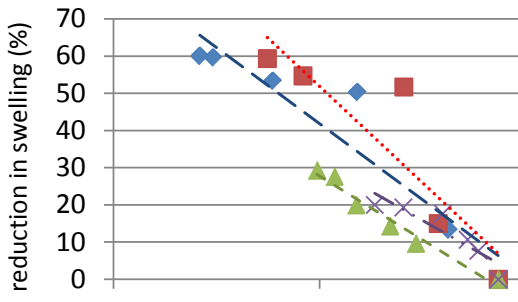

15

index of plasticity
- WP-lime

$\Delta$ WP-sea sand

- - linear (WP-lime)

......- linear (WP-sea sand)

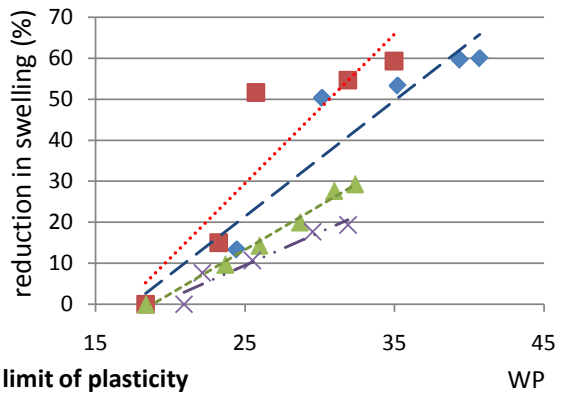

(b)

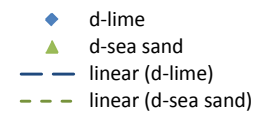

- d-cement

$\times \quad d$-silty sand

........ linear (d-cement)

—. - linear (d-silty sand)

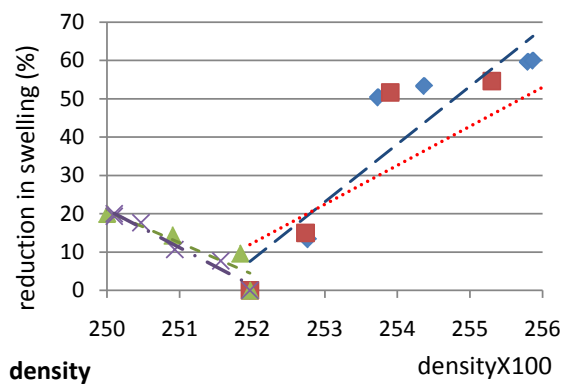

(d) (c)

IP density

Figure 13. Reduction in potential of swelling according to the limits of Atterberg and the density

\section{Discussion}

A reduction in the value of plasticity index when the percentage of stabilizer increases shows that these stabilizers influence the behavior of the clay; which is conform to the works of Djedid who showed that the limits of liquidity and plasticity are key parameters in the swelling behavior of clays [14]. On the other hand, the reduction in the plasticity index can be explained by:

- the rise in the quantity of pulverilent materials contained in the clayed material that has a plastifying power;

- the formation of a shell wrapping the fine grains of clay material by the minerals $\left(\mathrm{CaO} ; \mathrm{SiO}_{2} ; \mathrm{Al}_{2} \mathrm{O}_{3}\right)$ in cement and lime.

The growth of densities of samples from the stabilization at cement and lime according to their mixture proportion (2.498 to 2.578 ) may be explained by the fact that these two binders make clay more consistent. However, the reduction in the density of samples from the stabilization at sand according to the rise in their proportion and in that the granulometry is high may be justified by the fact that the additional sand makes higher the volume of the mixture whereas the mass goes down.

The rise in the limits of liquidity and plasticity, as the proportion of stabilizer 
increases, is in line with the results of Cabane [5], which is partly opposite to the works of Hachichi [3] who had observed a reduction in the limit of liquidity and a rise in the plasticity by using sand, cement and lime as stabilizer saline solutions.

The reduction in swelling by cement and lime (60\%) can be explained the fact that:

- when quick lime and a humid clayed soil are mixed, the quick lime hydrates rapidly by fixing a quantity of water; the divalent cations $\mathrm{Ca}^{2+}$ are then able to displace the monovalent cations on the surface of clays [2];

- on the whole, cement is viewed as a granulometric corrector improving the characteristics of soil. The stabilization of the clay soil with cement forms rapidly calcic hydrates. Thus, the main mineral of cement $\left(\mathrm{CaO} ; \mathrm{SiO}_{2} ; \mathrm{Al}_{2} \mathrm{O}_{3}\right)$ builds a shell around the clay as is the case with concretes [5].

The reduction in the swelling of clay by adding sand is more important when the components of the addition are bigger, showing the effect of the granularity of sand on the swelling (sea sand: $30 \%$ and silty sand $20 \%$ ). This reduction can be interpreted by the fact that the content in clay of the mixtures decreases by addition of sand which is an inert and pulverulent materal. In fact the voids created by the grains of sand in the clay are filled by a large part the swelling [15]. The works of Hachichi [3] also revealed a significant reduction in swelling up to $80 \%$ with $40 \%$ for the sea sand.

The significant reduction in the Togblécopés clay by different techniques of stabilization helps contribute to the preventions of works' pathologies, since this swelling soil causes a degree of growing saturation by capillarity under the buildings whereas the direct periphery remains subject to seasoning climate variations. This phenomenon causes differential movements of parts of the buildings leading to their excessive distortions. Thus, the reduction in the potential of swelling leads to the reduction in differential movements of some parts of the buildings. This results in the reduction in the excessive distortions in these parts.

\section{Conclusion}

The study showed that it is possible, considering cement, lime and sands as stabilizers, to reduce the swellingpotential of Togblecopéswellingsoils in Togo. The buildings undergoing excessive deformations due to swelling of the foundation soil of the zone, this reduction of swelling will thus allow the attenuation of the differential movements of the parts of the buildings thus reducing the appearance of the cracks. For the rest of this work, a study must be made through tests of determination of the mechanical strengths in order to appreciate the mechanical behavior of this swelling sol with respect to the stabilization.

\section{Acknowledgements}

This work could not have been carried out without the logistic and financial support from FORMATEC we express our sincere gratitude to. 


\section{References}

[1] Medjnoun, A. (2014) Analyse, caractérisation, prévision et modélisation du comportement des argiles gonflants. Thèse de doctorat, Université de Mouloud Mammeri, Algerie.

[2] Djaani, M. and Benmansour, S.F. (2011) Stabilisation des sols gonflants de la région d'In-Aménas par ajouts des liants hydrauliques (Chaux et Ciment). Mémoire de fin d'étude en vue de l'obtention du diplôme de Master en génie civil, Université de Kasdimerbahouargla, Algerie.

[3] Hachichi, A. (2009) Etude des phénomènes retrait-gonflement et stabilisation des sols gonflants de la région d'Oran. $19^{\text {ème }}$ Congrès Français de Mécanique, Marseille.

[4] Khattab, S.A. (2002) Etude multi-échelles d'un sol argileux plastique traité à la chaux. Thèse de doctorat, Université d'Orléans.

[5] Cabane, N. (2004) Sols traités à la chaux et aux liants hydrauliques: Contribution à l'identification et à l'analyse des éléments perturbateurs de la stabilisation. Thèse de doctorat, Ecole Nationale Supérieure des Mines de Saint Étienne.

[6] J. P. Sylvain,J.P., Aregba, A, Collart, J, Godonou,K.S. (1896) Carte géologique du Togo à l'échelle $1 / 500000,1^{\text {re }}$ édition, Notice explicative.

[7] Normes NF P 94-057 (1992) Analyse granulométrique des sols, méthode par sédimentation, AFNOR.

[8] Normes NF P 94-051 (1993) Détermination des limites d'Atterberg, limite de liquidité à la coupelle-limite de plasticité au rouleau, AFNOR.

[9] Normes NF P 94-053 (1991) Détermination de la masse volumique des sols fin en laboratoire, AFNOR.

[10] Normes XP P 94-091 (1995) Essai de gonflement à l'oedomètre-détermination des déformations par chargement de plusieurs éprouvettes, AFNOR.

[11] Amey, K.B., Neglo, K., Tamba, Johnson, A.K.C., Kouto, Y.E. and Nayo, E. (2014) Caractérisation physique de sables silteux au Togo. Afrique SCIENCE, 10, 53-69. http://www.afriquescience.info.

[12] Amey, K.B., Bedja, K. and Neglo,K. (2005) Etude de l'évolution transversale des distributions différentielle et cumulative et de la classe granulaire des granulats marins du littoral togolais. J. Rech. Sci. Univ. Lomé( Togo), Série E, 7, 13-20.

[13] Amey, K.B. (2006) Caractérisation des sédiments sableux du littoral togolais: expérimentation et détermination d'une formule de sable normale. Thèse de Doctorat unique en science de l'ingénieur à l'Université de Lomé (Togo).

[14] AissaMamoune, S.M., Bekkouche, A. and Djedid, A. (2001) Identification et prévision du gonflement de quelques sols de la région de Tlemcen, Algérie. Bulletin des laboratoires des ponts et chaussées, RÉF. 4375, 67-75.

[15] Louafi, B. and Derriche, Z. (2005) Effet d'un ajout de sable et l'influence de sa granulométrie sur les caractéristiques de gonflement d'une argile pure, Géoline-Lyon France- $23^{\text {rd }}-25^{\text {th }}$. 